\title{
Assessing Factors Affecting Formal Finance to Farmers in Ghana: Empirical Evidence of Sunyani West District
}

\author{
Zhongming Tan \\ Department of Economics and Trade, School of Finance and Economics \\ Jiangsu University, P.R. 212013 China \\ Krobea Asante Emmanuel (Corresponding author) \\ Department of Economics and Trade, School of Finance and Economics \\ Jiangsu University, P.R. 212013 China \\ E-mail: easante40@yahoo.com
}

Guoping Ding

Department of Accounting, School of Finance and Economics

Jiangsu University, China

Received: March 20, 2019 Accepted: April 3, 2019 Published: May 30, 2019

doi:10.5296/ber.v9i2.14861ＵRL: https://doi.org/10.5296/ber.v9i2.14861

\begin{abstract}
Farmers in Ghana plays a key role in increasing food supplies and a sector that contributes major to the country's gross domestic, yet they tend to have little or no access to formal credit finance. The study seeks to examine financial barriers that limit farmer's access to formal finance. The study utilized multiple regression model to validate the relationship between formal finance and financial barriers.

The empirical results shows that statistically barrier factors positively affect farmer's access to formal finance (FF). It effects on formal finance is significant. Therefore, Ministry of Food and Agricultural and Ghana Cocoa board, stakeholders and other nonprofit organizations in Ghana, should discover and liaise with formal financial institutions to mount good packages to support famers in rural communities in Ghana irrespective of these barriers.
\end{abstract}

Keywords: Formal finance, Farmers, Rural communities, Banks, Ghana 


\section{Introduction}

Agriculture remains the main economic activity and hires the common of the citizens in most developing economies and low-income countries. Universally, almost 450 million of household's main activity is agriculture. Agriculture is one of the major contributing sectors to the Gross domestic product to every economy in the globe. Nyamekye, A. B., et al. (2018).

Agriculture in developing economies, predominately in low-income economies engulf numerous of barriers such as low productivity, restricted access to markets for their products and services, adequate risk management products and services and the limit access to finance. Agriculture remains a key economic activity in the globe, particularly in Africa employing about 57 percent of the population. With all these, approximately $1 \%$ of financial lending goes to farmers in the agricultural sector. According to findex data, 2017, globally, only $4.7 \%$ of adults in rural communities in developing countries get access to loans from formal financial organizations and farmers holding bank account amassed. (Findex Report, 2017).

In Ghana, agriculture is one of the major contributing sector to the GDP. According to the Ministry of Food and Agriculture, Ghana has an arable land of $21.10 \%$ of its total land area. Agriculture plays a key economic role in Ghanaian districts, employing nearly $68 \%$ of the populace. The main occupations include farming on subsistence levels; crop production, livestock rearing, and fishing. These farms feed a huge number of people in the Ghanaian community. According to the Ministry of Food and Agriculture in their recent report, 80 percent of the Ghanaian populace depends on agriculture as their main sources of income and employment. These farmers in Ghana plays a key role in increasing food supplies and increased supply large conglomerates and corporations with inputs for their products. (Carroll 2015). Notwithstanding their socioeconomic significance, farmers tend to have little or no access to formal credit finance, which bounds their capacity to invest in the technologies and inputs they need to escalate their yields and incomes and reduce hunger and poverty, both their own and that of others. In fact, formal finance combined with modern technology leads to an increase in productivity. Both small and large scale farmers need formal finance to increase production (Das, Senapati\& John, 2009). Most agricultural financing in rural areas is offered by microfinance. The small and large scale farmers have differences when it comes to having access to both formal and informal finance. Small scale farmers do not have a problem to access only formal finance but also informal. Farmers need capital from the start of their production to the harvesting stage. The need for high yielding seeds, fertilizers and other inputs to increase production requires large capital.

Farmers not getting access to finance or credit facility affects scale and scope of agricultural productivity with no exception of Ghanaian farmers. It is a canker on the heads of farmers which limits their capacity to cultivate distinct kinds of crops and not able to acquire different adequate inputs for their farming operations. As production increases, more hands would be employed and this is not so when farmers do not have access to formal finance. In spite of the government of Ghana actively to make the agricultural sector very attractive, no empirical studies exist to examine the linkage between formal finance and barriers factors in Ghana. In addition, there seems to be very little interest on the formal finance about farmers in the rural 
communities in Ghana with regards to finance barriers options. Therefore, it is imperative to critically examine the level of barriers to deny farmers access to formal finance in Ghana, especially in the Sunyani District Assembly. The study attempts to investigate various financial barriers that limit farmer's access to formal finance for farming in the Sunyani West District of Ghana.

The remainder of this paper is organized as follows. Section two review the literature. The next section talks about the Agriculture sector in the Ghanaian community. Section four highlights research methodology. Section 4 reports the results of the study. The final section draws the conclusion

\section{Literature Review}

Formal finance has proven to be a powerful instrument for improving the welfare of the poor in every economic via consumption smoothening that reduces susceptibility to short-term income. Agriculture finance is defined as the acquisition and utilizations of capital, the factors of production that aides the procurement and management of other factors of capital, according to Famogbile, Akinola as cited in Flory, J. A. (2018). According to Shreiner andYaron, 2001), agriculture finance refers to public and private funds in the form of equity, gift or loan facility for refining social welfare via an extension of the agriculture sector. It is the establishment of numerous types of service dedicated to assistant both on and off farm agricultural events and business such as input provision, production, and distribution, wholesale and marketing.

Formal finance markets in remote communities are often inhibited by the property rights and high transactions cost. Notwithstanding these grievances, small holder's farmers have succeeded to produce for own consumption and the market. (Ortmann and King, 2006). Okurut et al, advocates that credit markets finance improves the productive capacity of the poor via financing investment in their human and physical capital. Farmer's access to formal (credit) is considered as imperative elements in levitation agriculture productivity.

Generally, it is recognized that financial institutions intermediation to expand, it is imperative that collateral is adequately available to borrowers and enforceable to lenders. It is the terrific way in which banks or financier can lessen the risk of losing monies as results of uncertainty is by requiring collateral. In fact, collateral lessens the problem of uncertainty, because recovering can be possible theoretically in event of the loan default. Collateral makes it possible to bring information asymmetries to the bearest minimum as it is often that physical assets are valued than human character(Yaron 1992). Moreover, the borrowers will discovery it costly to put valued collateral if they intend to default with the earnings of the loan since they will lose their collateral.

In assessing grievances associated with formal finance to farmers, the transaction cost of remote lending in developing economies are relatively high, mostly due to loan size, high frequency of transactions, large geographical spread, heterogeneity of borrowers and lack rural branch network as cited in Sacerdotal, 2005 and (Fianto, Gan et al. 2018). In relation to the extent of rural poverty especially in developing economies, the quantum of financial 
products required tends to be relatively small. The small size of loans in the rural communities emerges in a high transactions cost per loan, worsened by the heterogeneity of debtors, makes it tedious for formal financial institutions to recover the cost. The environmental spread of customers in rural communities and developing countries add up administrative cost after a credit facility is granted. However, debtors supervision costs are high, as are compliance costs for receivers. Financial institutions, therefore, have to attain a delicate trade-off between minimizing the loan default rate and lessening administrative costs (Basu, 2006) as all known in

Most literature stressed demographic such as gender, marital status and age as a contributing factor affecting the access to formal finance to farmers in developing countries. According to(Zhang 2008), contended that men access credit facility or finance more than women. They attributed their contention that, women are seen as poor and illiterate, therefore lacking the perilous collateral to use for sourcing finance. In South Africa, 90 percent of rural women have not accessed formal finance from financial institutions in rural communities. (Sabopetji and Belete (2009). Equally, Kaino (2005), revealed an irrelevant percentage of farming women accessing financial services in rural Myanmar. It has been argued that access to finance has the capacity to transformed women positively by this means aiding them to hold and control over their assets (Basu P (2006), and Glover, S. and S. Jones (2019. Age also plays a significant role in elucidating access to formal finance to farmers in rural areas. Various studies depicted distinct direction about the effect of age on access to finance. Meanwhile, studies by Sabopetji and Belete (2009) contend that decision to take credit declines with household age that is, there is a negative significant effect of age on access to formal finance. To add up, Kaino (2005) conducted studies and it was observed that age have a significant positive influence on access to finance in rural communities.

Additionally, famer's inability to access formal finance in rural communities is a result of the rate of interest which in turn effects investment. Dixon, J. (2019).maintained that investment is a diminishing function of interest rate. This infers that whenever interest rate increases, investment will ultimately drop, this is because with higher interest rate the likelihood of attaining profit out of investment is very low, and henceforth high-interest rate decreases the marginal efficiency of capital.

\subsection{Agriculture Finance in Ghana}

Ghanaian financial systems are categorized into three: formal, semi-formal and informal. The formal financial institutions are amalgamated under company's code 1963 which authorized them legal identities as limited liability companies, and under the banking law 1989 or non-banking law 1993 and licensed by the highest bank in Ghana, Bank of Ghana. The mandate is to provide financial services to individuals under the regulations of the Bank of Ghana.

In Ghana, the commercial banking system reaches only 10 percent of households according to the World Bank. (World Bank, 2017). This brings the role of the semi-formal and informal sectors, comprising rural banks, savings, and loans companies and these financial systems in financing the agriculture sectors cannot be emphasized. Formal financial institutions in 


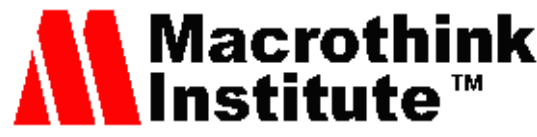

Business and Economic Research

ISSN 2162-4860

2019, Vol. 9, No. 2

Ghana have confirmed a lack of interest in the agriculture sector finance. (IFPRI (2010). Most formal financial institutions in Ghana believed that agriculture households are located in rural parts of the country, thus often isolated financial institutions found it thought-provoking to provide cost-effective and affordable services. Secondly, big swaths of the agriculture populace were questioned to the same weather and climate risks, thereby making it hard for providers of financial services to verge risks. However, financial institutions mainly in cities in Ghana, simply do not know much about the business of agriculture in order to invent profitability financial products. In fact, most farmers with agricultural production in Ghana had little or no education and knowledge on how contemporary banking institutions mechanism. With these challenges, some innovations are implemented in recent times including microfinance, community banking, Susu, and banking institutions making effort to bale financial services with non-financial services as some of the innovation in agricultural financing.

Existing studies depicts that Brong Ahafo and the Northern region of Ghana are the most under-banked part of the country. (IFAD, 2000). Many reasons warrant these regions tagged as underbanked and the common elucidation due to the fact there are no formal financial institutions in over 65 percent of the districts in both regions. One rural bank office serves an estimated average of $53000 \mathrm{~km} 2$. These are a terrific concern to farmers since most of the farmers and agro-processors depends on other financing sources such as Susu collectors.

Moreover, although banking systems are being reinforced in Ghana via supervision, they have a tendency to pay heed attention to their best clients to progress portfolio performance, rather than to reach out to new, and smaller clients. Financial institutions remain to have struggled with minor transactions due to high costs, perceived risks, collateral-based policies, and strong enticements to lend to the public sector as results of the high-interest rates on government's financial mechanisms (IFAD, 2000) as cited in Nyamekye, A. B., et al. (2018).

\subsection{Critique of Existing Literature Relative to the Study}

Although substantial studies have been done on formal finance on agricultural sectors in most developing countries, most of the studies have intense their works mostly on the formal finance barriers without finding out the reluctant of financial institutions not willing to give formal credit access to farmers in rural communities. Nevertheless, these research studies have been carried on the developing countries but little or none of these studies looked at investigating factors affecting formal finance to farmers in rural communities utilizing the multiple regression model. Therefore, there existed a research gap that was to be filled by this research work in examining the factors or barriers that have accounted for famer's access to formal finance in Ghana, particularly at Sunyani District using multiple regression model.

\section{Methodology}

\subsection{Research Design}

The study employed both qualitative and quantitative approach to give a depiction of the formal finance and barriers affecting access to formal finance to support Farmers in Ghana. These research design chosen were utilized to gather and analyze data which aid to establish 
the associations between the study variables.

\subsection{Population and Sample of the study}

The population of the study involved five communities in the Sunyani West District Assembly of Ghana. With this, approximately seventy-six (76) farmers were randomly selected from each of the communities for the investigation. The name of the communities is displayed in Appendix.

\subsection{Data Collection Processes}

The study used questionnaires to gather data from 250 farmers from the chosen communities on the financial barriers that limit farmer's access to formal finance for farming in the district, and the reasons why financial institutions are reluctant to offer formal finance to farmers in the Sunyani districts. The questionnaires of the study were piloted or tested before it was deployed to ensure readability and efficiency (Idolor, 2010). Together with this, experts from the Ministry of Food and Agriculture and Ghana Cocoa Board judged the questionnaires for value guarantee of the purposes of the study, therefore extraneous items were dismissed before issued to respondents. The questionnaires were made of five (4) sections. The first section deals with participants profile such as age, gender, income, education level and year of farming. The second section asked questions on the main sources of formal finance to farmers. The next section addressed the barriers limiting access of formal finance to the farmers and the last sections D dealt with the reasons why financial institutions are reluctant to give formal finance to farmers in the district. The sections $\mathrm{B} \& \mathrm{C}$ of the study questionnaires were affixed with a Likert scale from 1 (not effective) to 4 (very effective). Moreover, the rest of the sections followed the standard multiple choice Yes/No format.

\subsection{Model Specification}

The study used multiple regression model to examine the barriers limiting farmer's access to formal finance, and it is given by:

$$
\begin{gathered}
F F=\beta_{0}+\beta_{1} \text { COLL }_{1}+\beta_{2} E D U L V L_{2}+\beta_{3} F A R E P R_{3}+\beta_{4} L_{N S I Z E_{4}}+\beta_{5} I N R A T_{5} \\
+\beta_{6} D M G R F A R_{6}+\varepsilon_{t}
\end{gathered}
$$

Where FF is formal Finance, EDULVL is Educational level of farmers, FAREPR represents farming experience, LNSIZE is Land Size, INRAT is an interest rate of the farmers, DMGRFAR represents demographic of farmers such as age and sex, education level and $\boldsymbol{\beta}_{0}$ indicates the constant parameter of the model. $\left(\boldsymbol{\beta}_{1}-\boldsymbol{\beta}_{6}\right)$ represents the coefficients of the independent variables on the dependent variable and cit is the stochastic or error term.

The study performed the correlation coefficient, Anova and regression coefficient as the methods to examine the impact of the independent variables on the dependent in the regression model thus, the regression model was estimated through the aid of Statistical Package for Social Sciences (SPSS).

\section{Data Presentation, Analysis, and Findings}

The descriptive analysis gives and analysis the data from the structured questionnaires from 
the respondents. Two hundred and fifty respondents (farmers) took part form the sampled communities. Two hundred (220) respondents out of the chosen number from each community completed the questionnaires of the study, which the selected respondents are all farmers from cocoa farming, cassava, plantain, and Poultry. Summary of the results are depicted below,

Table 1. Respondent Profile

\begin{tabular}{|l|l|l|l|}
\hline Description & & Percentages & Frequency \\
\hline Gender & Male & 73 & 160 \\
\hline & Female & 27 & 80 \\
\hline & & & \\
\hline Age Group & $<30$ years & 30 & 67 \\
\hline & $31-40$ years & 36 & 80 \\
\hline & 41 and above years & 34 & 73 \\
\hline Edu. Level & & & \\
\hline & High School & 53 & 116 \\
\hline & Diploma & 40 & 89 \\
\hline & First Degree & 7 & 15 \\
\hline Income Level & & & \\
\hline & $500 \$$ & 14 & 30 \\
\hline & $700 \$$ & 18 & 40 \\
\hline & $900 \$$ & 59 & 130 \\
\hline & $1000 \$$ & 9 & 20 \\
\hline Year of Farming & $<5$ years & 23 & 50 \\
\hline & $6-10$ years & 21 & 46 \\
\hline & $11-15$ years & 32 & 70 \\
\hline & $>16 y e a r s$ & 24 & 64 \\
\hline & & & \\
\hline
\end{tabular}

From the table above, 73 percent of the farmers are males, and (27) percent of them are females. Sixty Seven(67) of the respondents (farmers) representing thirty (30) percent of them are below the age of thirty (30) and thirty-six percent(36) between the ages of 31-40 years, and thirty-four (34) percent of the respondents were above forty- one (41) years. However, 30 of the sampled farmers representing 14 percent have income levels of approximately $\$ 500$ every month, eighteen (18) percent of them have approximately $700 \$$ a month, nine (9) percent of the farmers receive an average income of $\$ 1000$ each month and the highest number of the sample farmers representing 59 percent have the average of $900 \$$ each month. Meanwhile, Thirty (32) percent of the farmers had at least fifteen years' farming experience.

\section{Factors affecting Formal Finance to Farmers.}


Table 2. Descriptive summary statistics

\begin{tabular}{|l|l|l|l|l|}
\hline Variable & Mean & Std. Dev. & Min & Max \\
\hline FF & 1.166 & 0.075 & 0.192 & 0.222 \\
\hline EDULVL & 6.066 & 0.466 & 5.117 & 8.334 \\
\hline FAREPR & 0.662 & 0.136 & 0.385 & 0.883 \\
\hline LNSIZE & 1.323 & 0.726 & 0.168 & 0.266 \\
\hline INRAT & 0.734 & 0.526 & 3.712 & 3.812 \\
\hline DEGRFAR & 1.211 & 0.721 & 1.561 & 1.461 \\
\hline
\end{tabular}

The table above shows the summary statistics of both dependent and independent variables of the study. From the table, statistically, an average of 1.16 is the formal finance allotted to farmers by financial institutions. It goes with a range of 0.03 with a maximum of 0.2 and a minimum of 0.19 . On the other side, an average of 6.06 of formal finance is affected by the educational level of farmers with a minimum of 8.33 and a maximum of 5.11. However, most of the barriers affected formal finance with small average.

Table 3. Correlation Coefficient

\begin{tabular}{|l|l|c|c|c|c|c|}
\hline & FF & EDULVL & FAREPR & LNSIZE & INRAT & DEGRFAR \\
\hline FF & 1 & & & & & \\
\hline EDULVL & 0.146 & 1 & & & & \\
\hline FAREPR & 0.365 & 0.433 & 1 & & & \\
\hline LNSIZE & 0.2373 & 0.128 & 0.035 & 1 & & \\
\hline INRAT & 0.2373 & -0.510 & 0.301 & -0.221 & 1 & \\
\hline DEGRFAR & 0.501 & 0.648 & 0.522 & 0.3005 & 0.333 & 1 \\
\hline
\end{tabular}

Table 3 provides a correlation matrix of all variables. All the barrier variables except DEGRFAR are positively and highly correlated with each other. $(\mathrm{P}<0.5)$ which confirms that, these factors are limit farmers for formal finance. Empirically, from the correlation table, most of the stated barrier factors variables significantly impact formal finance in Sunyani District, meaning that, it contributes to farmers not getting access to formal finance. However, there is a positive relationship between Demographic factors and formal finance but the effect is insignificant since the $(\mathrm{P}>0.5)$. This means that, demographic factors such as age, gender, and income limit farmers accessibility of formal finance but the effect is not significant.

Table 4. Regression of the model

\begin{tabular}{|c|c|c|c|c|c|}
\hline Multiple R & \multicolumn{2}{|c|}{ R Square } & \multicolumn{2}{|c|}{ Adj R-squared } & Std. Error of Estimate \\
\hline 0.55 & 0.6 & & 0.48 & & 2.27 \\
\hline \multicolumn{6}{|c|}{ Analysis of the Variance Testing } \\
\hline & $d f$ & $S S$ & $M S$ & $F$ & Prob $>F$ \\
\hline Model & 4 & 100.42 & 8.706 & 2.10 & $0.045 b$ \\
\hline Residuals & 1 & 9.54 & 9.40 & & \\
\hline Total & 5 & 109.96 & & & \\
\hline
\end{tabular}


Table 5. Regression of the model

\begin{tabular}{|l|l|l|l|l|}
\hline Variable & Coefficient & Standard Error & t-Statistics & Prob. \\
\hline Constant & 0.3083 & 0.3177 & 0.970 & $0.345^{* *}$ \\
\hline EDULVL & 10.72 & 2.49 & 4.305 & $0.001^{*}$ \\
\hline FAREPR & 2.15 & 1.82 & 1.181 & $0.002^{*}$ \\
\hline LNSIZE & 2.27 & 1.67 & 1.35 & $0.051^{*}$ \\
\hline INRAT & 2.02 & 3.53 & 0.572 & $0.010^{*}$ \\
\hline DEMGRFAR & 11.41 & 2.24 & 5.09 & $0.001^{*}$ \\
\hline
\end{tabular}

$*$, ** indicates $1 \%, 5 \%$ significance respectfully.

The results of the table (4), the independent variables shows about $48 \%$ of the difference in Formal finance. This means that, ( Educational level of farmers, farming experience, Land Size, interest rate of farmers, demographic of farmers limits famers access to formal finance with $48 \%$, while other factors not discussed in the study contributes $52 \%$. It is vivid that there is a relationship between the variables of the study (Multiple $\mathrm{R}$ correlation coefficient), showing 0.55 .

Moreover, with the ANOVA testing statistics as illustrated above (table (5), the independent variables gives a good fit at the significance $F$ value since is $<0.5$, for that reason the model was statistically significant. With this, the study accepts the alternative hypothesis and reject the null hypothesis, since the significant $\mathrm{P}$-value is $<0.05$ ( $\mathrm{P}$-Value is 0.045

As revealed from Table 6, barriers factors signified by educational level, farming experience, land size, interest rate and demographic positively affect farmer's access to formal finance $(\mathrm{FF})$. It effects on farmers finance are negative. (Coff. =-29.02) and their effects are significant. ( $\mathrm{P}<0.5$, ) Based on the findings, it indicates that there is significant positive correlation between formal fiancé and the barrier factors.

However, farmers were asked to rate the following factors that financial institutions based on to limit their access to formal finance to support their farming works. The factors are the following: the ability to pay the loan quickly, Gender (male or female), portfolio performance purposes, principal credit risk, collateral purpose, and little or No banking education mechanisms on Likert scale from 1 ( strongly agree) to 5 ( strongly disagree).

Table 6. Reasons by financial institutions reluctant to give formal finance

\begin{tabular}{|l|l|l|l|l|}
\hline Reason & Frequency & Percentage \% & Mean & Standard Deviation \\
\hline $\begin{array}{l}\text { Inability to pay the Credit } \\
\text { facility as expected }\end{array}$ & 200 & $90 \%$ & $4.3(3)$ & 0.01 \\
\hline Gender Issues & 210 & $95 \%$ & $5.1(1)$ & 0.81 \\
\hline Portfolio performance purposes & 154 & $70 \%$ & $3.9(5)$ & 0.09 \\
\hline Collateral Purpose & 145 & $65 \%$ & $3.5(6)$ & 0.49 \\
\hline Little or No banking Mechanism & 205 & $93 \%$ & $4.4(2)$ & 0.04 \\
\hline Principal credit Risk & 189 & $85 \%$ & $4.0(4)$ & 0.04 \\
\hline
\end{tabular}


Empirically, from table 6, farmers agreed that the most reason why financial institutions are reluctant to give out loans or formal finance is associated with gender issues. It had an average mean rating of 5.1 signifying $95 \%$ of the total respondents. They buttressed their argument that gender issue especially women and marital issues deny banks to give formal credit to farmers. Most financial institutions have seen women as poor and illiterate, thus lacking the perilous collateral to use for sourcing funds.

Another reason that according to farmers prevent financial institutions to provide formal farmers is the fact that financial institutions were with the view that, farmers have little or no banking mechanism. 205 of the respondents representing 93\% agreed to that. In fact, most farmers with agricultural production in Ghana had little or no education and knowledge on contemporary banking institutions mechanism.

Inability to pay the credit facility on due time is another major reason that prevents the banking institutions to support farmers in agriculture. It had a mean rating of 4.3 embodying $90 \%$. Most of the farmers are unable to pay the credit facility by banks. Thereby becomes tedious to support farmers on formal finance especially farmers in deprived communities. However, the least reason associated with the banking institutions inability to provide formal finance to farmers is portfolio performances purposes having 3.9 average mean rating signifying $70 \%$ percent. Financial institutions have the tendency to pay heed attention to their best clients to progress portfolio performance, rather than to reach out to new, and smaller clients. Framers are seen as small, and new clients by financial institutions.

\section{Conclusions and Recommendations}

The study examined the factor barriers affecting formal finance to farmers in rural communities in Ghana, particularly in the Sunyani West District Assembly. However, farmers were asked to rate factors that makes financial institutions reluctant to offer finance to support their farming. The findings indicated that, majority of the famers agreed that, gender issues most especially women and marital sex is the major problem denying financial institutions to offer finance to support farmers. However, 205 of the respondent signifying 93 were with the view that farmers having little or no banking education mechanism counts the financial institution reluctantly providing formal finance. The findings validate preceding empirical studies done by Sabopetji, (2009), Kaino, (2005) on reasons warranted the bank's decisions not offer formal finance to farmers.

On the basis of the results, the study would conclude that farmers with agricultural production in Ghana should be educated on the mechanisms on the contemporary banking institutions in Ghana. This will ease the unwillingness of financial institutions to give loans to support agricultural sectors. The study however employed multiple regression to investigate the barriers affecting formal finance to famers in Sunyani West District Assembly, Ghana. The results revealed that barrier factors signified by educational level, farming experience, land size, interest rate, and demographics positively affect farmer's access to formal finance (FF). It effects on formal finance are significant. With this, Ministry of Agricultural and Ghana Cocoa board and other nonprofit organizations in Ghana should discover and liaise with formal financial institutions to mount good packages to support farmers in rural 
communities in Ghana irrespective of these barriers. However, intensive education should be the Ministry of Food and Agriculture to change some negative perceptions of farmers, thus aid them with good strategies to befit the acquisition of formal finance from financial institutions.

\section{Future Research}

Future studies should consider using the financial institutions as a case study on the exact reasons preventing them to offer formal finance to farmers in rural communities.

\section{References}

Aldrich, J., \& Nelson, D. (1984). Linear Probability, Logit, and Probit Models. SAGE Publications, Beverly Hills. pp. 3-35. https://doi.org/10.4135/9781412984744

Aliero, H. M. (2009). Gauging Nigeria in Rural Finance: a Survey of Country-Experience. NDIC Q., 19(1\&2), 50-56.

Anders, I. (2002). Access to Formal Finance in Kenyan Manufacturing. Sin Working Paper Series. W/p, 3, 3-29.

Atieno, R. (2001). Formal and I nformal Institutions'Lending Policies and Access to Credit by Small-Scale Enterprises in Kenya: an Empirical Assessment. AERC Research Paper iii.

Babasanya, B., Bolagun, O., Zungum, A., \& Olowohunwa, J. (2008). Rural Development: An Approach to Poverty Alleviation in Nigeria. Int. J. Econ. Develop. Univ. Consortia, 2(1), $28-41$.

Badayi, A. S. (2002). Towards Effective Poverty Alleviation Strategies. NCEMA Policy Analysis Series, 3(8), 1-16.

Basu, P. (2006). Improving Access to Finance for India's Rural Poor, World Bank, Washington. D.C. pp. 1-88. https://doi.org/10.1596/978-0-8213-6146-7

Beck, T., \& La Torre (2006). The Basic Analytics of Access to Financial Services, Paper Presented at the Latin American Regional Study on Access to Finance. World Bank, Washington D.C. https://doi.org/10.1596/1813-9450-4026

Beck, T., \& Levine. R. L. (2000). Finance and the Source of Growth. J. Finan. Econ., 58, 261-300. https://doi.org/10.1016/S0304-405X(00)00072-6

Burgess, R., \& Pande, R. (2003). Do Rural Banks Matter? Evidence from the Indian Social Banking Experiment. Research Paper.

Carroll, T. (2015). Access to Finance and the Death of Development in the Asia-Pacific. Journal of Contemporary Asia, 45(1), 139-166.

https://doi.org/10.1080/00472336.2014.907927

Classens, S., Dabos, G., Klingebile, D., \& Laeven, L. (2003). The Growing Importance of Networks in Finance and its Effect on Competition. In A. Nagurnay, (Eds.), Innovations in Financial and Economic Networks (pp. 110-135), Edward Elgar Publishers, Northampton. 


\section{$\triangle$ Macrothink}

Business and Economic Research ISSN 2162-4860

Das, A., Senapati, M., \& John, J. (2009). Impact of agricultural credit on agriculture production: An empirical analysis in India. Reserve Bank of India Occasional Papers, 30(2), $75 \mathrm{e} 107$.

Dixon, J. (2019). Concept and Classifications of Farming Systems. Encyclopedia of Food Security and Sustainability. P. Ferranti, E. M. Berry, \& J. R. Anderson. Oxford, Elsevier: 71-8. https://doi.org/10.1016/B978-0-08-100596-5.22155-0

Famogbile Akinola (2010). The Challenges of Agricultural Finance in Nigeria: Constraints to sustainable Agricultural and Economic Revival Ghana Statistical Service (PHC 2010) www.statsghana.gov.gh

Fianto, B. A., et al. (2018). Equity financing and debt-based financing: Evidence from Islamic microfinance institutions in Indonesia. Pacific-Basin Finance Journal, 52, 163-172. https://doi.org/10.1016/j.pacfin.2017.09.010

Fleising, H., \& de la Pena, N. (2003). Legal and Regulatory Requirements for Effective Rural Financial Markets. Paper for Paving the Way Forwards: an International Conference on Best Practice in Rural Finance. Washington D.C. pp. 12-16.

Flory, J. A. (2018). Formal finance and informal safety nets of the poor: Evidence from a savings field experiment. Journal of Development Economics, 135, 517-533. https://doi.org/10.1016/j.jdeveco.2018.07.015

Glover, S., \& Jones, S. (2019). Can commercial farming promote rural dynamism in sub-Saharan Africa? Evidence from Mozambique. World Development, 114, 110-121. https://doi.org/10.1016/j.worlddev.2018.09.029

Hainz, C., \& Teksoz, U. (2006). Access to Finance: the Role Inside Versus Outside Collateral in Transition Economies.

Kaino, T. (2005). Rural Credit Market in Myanmar: A Study of Formal and Non-formal Lenders. Asian. J. Agric. Devel., 4(1), 3-15.

Nyamekye, A. B. et al. (2018). Governance arrangements and adaptive decision-making in rice farming systems in Northern Ghana. NJAS - Wageningen Journal of Life Sciences, 86-87, 39. https://doi.org/10.1016/j.njas.2018.07.004

Sebopetji, T., \& Belete, A. (2009). An application of probit analysis to factors affecting small-scale farmers' decision to take credit: A case study of the greater Letaba local municipality in South Africa. African Journal of Agricultural Research, 4(8), 718e723.

World Bank (1999). World Development Report, Washington, D.C.

Yaron, J. (1992). Assessing Development Finance Institutions. A Public Interest Analysis.

Zhang, G. (2008). The choice of formal or informal finance: Evidence from Chengdu, China. China Economic Review, 19(4), 659-678. https://doi.org/10.1016/j.chieco.2008.09.001 


\section{Copyright Disclaimer}

Copyright for this article is retained by the author(s), with first publication rights granted to the journal.

This is an open-access article distributed under the terms and conditions of the Creative Commons Attribution license (http://creativecommons.org/licenses/by/3.0/). 